\title{
KOROZNÍ ODOLNOST A MIKROSTRUKTURA ŽÁROVZDORNÉ FORSTERIT-SPINELOVÉ KERAMIKY
}

\author{
CORROSION RESISTANCE AND MICROSTRUCTURE OF REFRACTORY \\ FORSTERITE-SPINEL CERAMICS
}

\author{
Martin Nguyen ${ }^{*}, 1$ Radomír Sokolár ${ }^{1}$ \\ "nguyen.m@fce.vutbr.cz \\ ${ }^{1}$ Vysoké učení technické v Brně, Fakulta stavební, ústav technologie stavebních hmot a dílců, Veveří 331/95, 60200 Brno, Česká republika
}

\begin{abstract}
Abstrakt
Tento článek se zabývá procesem syntézy žárovzdorné forsterit-spinelové keramiky za použití vysokoteplotního popílku a reaktivního oxidu hlinitého jako vstupních surovin. Vstupní suroviny byly předupraveny, smíchány a vypáleny při $1550^{\circ} \mathrm{C}$ po dobu $3 \mathrm{~h}$. Vypálené zkušební vzorky byly charakterizovány pomocí RTG difrakční analýzy a rastrovacího elektronového mikroskopu. Rovněž byla zkoumána pórovitost, nasákavost, objemová hmotnost, žárovzdornost, únosnost v žáru, odolnost proti změnám teplot a korozní odolnost vůči železu a slínku jako korozních médií. Vliv různých surovinových směsí byl studován v souladu s výslednými vlastnostmi, mikrostrukturou a korozní odolností všech vypálených vzorků. Vyšší množství spinelu ve vzorcích vedlo ke zlepšení mikrostruktury, mechanických vlastností a odolnosti proti změnám teplot.
\end{abstract}

\section{Klíčová slova}

Forsterit, spinel, korozní odolnost, žárovzdornost, mikrostruktura

\begin{abstract}
This article examines the process for the synthesis of forsterite-spinel refractory ceramics utilizing fly ash and reactive alumina as raw materials. Raw materials were pre-treated, mixed, and sintered at $1550{ }^{\circ} \mathrm{C}$ for $3 \mathrm{~h}$. Sintered samples were characterized by XRD and SEM. Porosity, water absorption, bulk density, refractoriness, refractoriness under load, thermal shock resistance and corrosion resistance by iron and clinker as corrosive media were also investigated. The impact of different raw material mixtures was investigated in accordance with the resulting properties, microstructure, and corrosion resistance of all fired samples. Higher amount of spinel in fired samples led to improved microstructural and mechanical properties and thermal shock resistance.
\end{abstract}

Key words

Forsterite, spinel, corrosion resistance, refractoriness, microstructure

\section{1 ÚVOD}

Žárovzdorná forsteritová keramika se $\mathrm{v}$ současnosti využívá především v cementářském a metalurgickém průmyslu jako vyzdívka pecí díky vysoké teplotě tání forsteritu až $1890{ }^{\circ} \mathrm{C}$. Forsterit má chemický vzorec $2 \mathrm{MgO} \cdot \mathrm{SiO}_{2}$ [1], [2], [3]. Forsteritová keramika je také využívána v průmyslu zpracování barevných kovů také jako vyzdívka a v elektrotechnickém průmyslu pro spojení keramiky s kovem díky podobnému koeficientu délkové teplotní roztažnosti forsteritu s koeficientem kovů [4], [5].

Kvůli poměrně vysokému koeficientu délkové teplotní roztažnosti má čistá forsteritová keramika poměrně malou odolnost proti náhlým změnám teplot. Tuto vlastnost lze zlepšit přidáním hořečnato-hlinitého spinelu (MA-spinel; spinel). Již přidáním malého množství (10-15\%) spinelu dochází ke zlepšení v oblasti mikrostruktury, mechanických vlastností a zejména zvýšení odolnosti proti změnám teplot [6], [7]. Chemický vzorec spinelu je $\mathrm{MgO} \cdot \mathrm{Al}_{2} \mathrm{O}_{3}$ a lze jej syntetizovat $\mathrm{z}$ oxidu hlinitého a oxidu hořečnatého.

Hlavním cílem tohoto př́spěvku bylo stanovení korozní odolnosti a vlivu různých korozivních médií na navržené směsi forsterit-spinelové keramiky v souladu s vlivem na jejich mikrostrukturu. Byly zkoumány zejména fyzikálně-mechanické vlastnosti jako jsou pórovitost, nasákavost, objemová hmotnost, pevnost v tahu za ohybu, 
mineralogické složení pomocí RTG difrakční analýzy, mikrostruktura pomocí rastrovacího elektronového mikroskopu, korozní odolnost a žárovzdorné vlastnosti.

\section{LITERÁRNÍ PŘEHLED/POPIS SOUČASNÉHO STAVU}

Doposud bylo realizováno mnoho studií týkajících se využití forsteritu v kruhových laserech [8], jako biomateriálu pro transplantaci kostí v biomedicíně [9], [10], nebo jako materiálu pro kompozitní nanomateriály [11], [12]. Jak již bylo zmíněno, primární využití forsteritové keramiky je jako vyzdívka rotačních a metalurgických pecí díky vysoké teplotě tavení až $1890^{\circ} \mathrm{C}$ a únosnosti v žáru nad $1600^{\circ} \mathrm{C}$ nebo v elektrotechnice pro spojení keramiky s kovem při výrobě různých součástek jako jsou např́íklad rezistory díky koeficientu teplotní roztažnosti podobnému kovům.

Vysokoteplotní popílek, jenž je produkován jako druhotná surovina z elektráren spalující uhlí, lze využít jako levný zdroj oxidů hlinitého a křemičitého. Využitím i malého množství druhotné suroviny jako náhrady běžných vstupních surovin je velmi př́nosné pro ekologii a má také pozitivní enviromentální vliv na udržitelný rozvoj v budoucnosti. Oxid křemičitý i hlinitý lze využít pro slinování žárovzdorné keramiky. Elektrárenský popílek byl již v minulosti využit v mnoha vědeckých studiích s dobrými výslednými vlastnostmi [13], [14], [15], [16].

Spinelová keramika se společně s magnezitovou keramikou využívá také jako vyzdívka rotačních pecí pro výrobu cementu a vápna díky velmi vysokému bodu tání spinelu $2135^{\circ} \mathrm{C}$ a oxidu hořečnatého $2800{ }^{\circ} \mathrm{C}$, nižším koeficientem teplotní roztažnosti v porovnání s forsteritovou keramikou a také dobrou odolností proti náhlým změnám teplot a korozní odolností [6], [7], [11], [17]. Navzdory využití popílku pro syntézu žárovzdorné hlinitokřemičitanové keramiky nebylo provedeno mnoho výzkumných prací zabývajících se využitím elektrárenského popílku pro syntézu jiných žárovzdorných materiálů obsahujících oxidy křemíku anebo hliníku, jako je např́iklad forsterit-spinelová keramika.

\section{METODIKA}

Vstupní suroviny pro syntézu forsterit-spinelové keramiky byly obdrženy z různých oblastí. Kalcinovaný kaustický magnezit (CCM 85) ze Slovenských magnezitových závodů v Jelšavě, mastek od společnosti Fichema, ČR, olivín od norské společnosti A/S Olivin, vysokoteplotní popílek z elektrárny Mělník, reaktivní oxid hlinitý od společnosti Almatis, Německo a kaolin Sedlec Ia od společnosti Sedlecký kaolin. Chemické složení vstupních surovin je zobrazeno v Tab. 1 a bylo stanoveno pomocí chemické analýzy nebo rentgenové fluorescence.

Tab. 1 Chemické složení vstupních surovin.

\begin{tabular}{cccccccc}
\hline \multirow{2}{*}{ Vstupní suroviny } & $\begin{array}{c}\mathrm{MgO} \\
{[\%]}\end{array}$ & $\begin{array}{c}\mathrm{SiO}_{2} \\
{[\%]}\end{array}$ & $\begin{array}{c}\mathbf{A l}_{2} \mathbf{O}_{3} \\
{[\%]}\end{array}$ & $\begin{array}{c}\mathbf{C a O} \\
{[\%]}\end{array}$ & $\begin{array}{c}\mathbf{F e}_{2} \mathbf{O}_{3} \\
{[\%]}\end{array}$ & $\begin{array}{c}\mathbf{K}_{2} \mathbf{O}+\mathbf{N a}_{2} \mathbf{O} \\
{[\%]}\end{array}$ & $\begin{array}{c}\mathbf{Z Z}^{*} \\
{[\%]}\end{array}$ \\
\hline CCM 85 & 85,0 & 0,5 & 0,8 & 5,2 & 7,30 & 0,20 & 1,0 \\
Mastek & 31,5 & 59,1 & 1,0 & 1,0 & 0,7 & 0,2 & 6,5 \\
Olivín & 24,1 & 64,7 & 1,0 & 0,7 & 8,80 & 0,50 & 1,0 \\
Reaktivní oxid hlinitý & 0,0 & 0,0 & 99,7 & 0,0 & 0,03 & 0,12 & 0,1 \\
Popílek & 1,4 & 57,3 & 29,3 & 2,2 & 5,10 & 1,70 & 1,2 \\
Kaolin Sedlec Ia & 0,5 & 46,8 & 36,6 & 0,7 & 0,85 & 1,20 & 13,2 \\
\hline
\end{tabular}

*ztráta žíháním

Byly navrženy 4 různé směsi, které byly rozděleny do dvou sad v závislosti na zdroji oxidu hlinitého pro syntézu spinelu $\left(\mathrm{MgO} \cdot \mathrm{Al}_{2} \mathrm{O}_{3}\right)$ společně s oxidem hořečnatým. První sada dvou směsí obsahovala jako zdroj $\mathrm{Al}_{2} \mathrm{O}_{3}$ vysokoteplotní popílek (označeny P-S10, P-S15). Druhá sada dvou směsí obsahovala jako zdroj $\mathrm{Al}_{2} \mathrm{O}_{3}$ reaktivní oxid hlinitý (označeny A-S10, A-S15). Označení S10 a S15 vyjadřuje teoretický obsah spinelu po výpalu v množství 10 \% a 15 \%. Surovinové složení všech navržených směsí je obsaženo v Tab. 2.

Tab. 2 Surovinové složení navržených směsí.

\begin{tabular}{ccccccc}
\hline $\begin{array}{c}\text { Označení } \\
\text { směsi }\end{array}$ & $\begin{array}{c}\text { CCM 85 } \\
\text { [hm. \%] }\end{array}$ & $\begin{array}{c}\text { Mastek } \\
\text { [hm. \%] }\end{array}$ & $\begin{array}{c}\text { Olivín } \\
\text { [hm. \%] }\end{array}$ & $\begin{array}{c}\text { Vysokoteplotní } \\
\text { popílek [hm. \%] }\end{array}$ & $\begin{array}{c}\text { Reaktivní oxid } \\
\text { hlinitý [hm. \%] }\end{array}$ & $\begin{array}{c}\text { Kaolin Sedlec } \\
\text { Ia [hm. \%] }\end{array}$ \\
\hline P-S10 & 43,5 & 12,4 & 24,8 & 14,3 & - & 5,0 \\
P-S15 & 45,9 & 8,0 & 15,9 & 25,2 & - & 5,0 \\
A-S10 & 40,0 & 17,0 & 34,0 & - & 4,1 & 5,0 \\
A-S15 & 39,6 & 16,0 & 32,1 & - & 7,3 & 5,0 \\
\hline
\end{tabular}


Všechny směsi byly připraveny předúpravou hrubších vstupních surovin tak, aby propadly sítem o velikosti oka 0,064 mm. Po smíchání vstupních surovin dle návrhu byly směsi homogenizovány v rotačním mechanickém homogenizátoru po dobu 24 hodin. Po smíchání s vodou bylo pomocí Pfefferkornova přístroje zhotoveno plastické těsto o optimální konzistenci a z něj byly poté formovány zkušební vzorky ve tvaru kvádru o rozměrech $20 \times 25 \times 100 \mathrm{~mm}$ pro stanovení pevnosti v tahu za ohybu a zkoušek vakuové nasákavosti, ve tvaru kužele o výšce $50 \mathrm{~mm}$ a průměru $50 \mathrm{~mm}$ pro stanovení únosnosti v žáru, ve tvaru kvádru o rozměrech $114 \times 64 \times 64 \mathrm{~mm}$ pro stanovení odolnosti proti změnám teplot a ve tvaru kvádru se čtvercovou podstavou o hraně $100 \mathrm{~mm}$ a výšce $76 \mathrm{~mm}$ s otvorem a průměru a výšce $55 \mathrm{~mm}$ pro stanovení korozní odolnosti. Ze stejného plastického těsta také zkušební žároměrky ve tvaru jehlanu dle ČSN EN 993-13. Zkušební vzorky byly poté vysušeny v laboratorní sušárně při teplotě $105^{\circ} \mathrm{C}$ do konstantní hmotnosti. Po sušení následoval výpal zkušebních vzorků při teplotě $1550{ }^{\circ} \mathrm{C}$ s teplotním nárůstem $4{ }^{\circ} \mathrm{C} / \mathrm{min}$ a dobou výdrže 3 hodiny při maximální teplotě.

Na vypálených zkušebních vzorcích bylo provedeno stanovení zdánlivé pórovitosti, nasákavosti a objemové hmotnosti (ČSN EN 993-1), délkové změny výpalem (ČSN EN 993-10), žárovzdornost (ČSN EN 993-12) na zkušebních žároměrkách, které byly umístěny do pozorovací pece s fotoaparátem, jenž umožňuje pozorování v reálném čase, únosnost v žáru (ISO 1893) u které byla sledována teplota při $0,5 \%$ deformaci $\left(\mathrm{T}_{0,5}\right)$, korozní odolnost (ČSN P CEN 15418) kelímkovou korozní zkouškou s korozními médii železem a slínkem, měření hloubky průsaku pomocí optického mikroskopu a odolnost proti změnám teplot (ČSN EN 993-11) metoda B, parametr reziduální pevnost $\mathrm{v}$ ohybu je definován jako poměr pevnosti $\mathrm{v}$ tahu za ohybu cyklovaných vzorků k pevnosti $\mathrm{v}$ tahu za ohybu necyklovaných vzorků. Také byla provedena RTG difrakční analýza pro stanovení mineralogického složení se zdrojem záření $\mathrm{CuK} \alpha$, urychlovací napětí $45 \mathrm{kV}$ a proud $40 \mathrm{~mA}$, pro kvantifikační analýzu byl využit fluorit $\left(\mathrm{CaF}_{2}\right)$ jako standard. Mikrostruktura byla pozorována pomocí optického mikroskopu a rastrovacího elektronového mikroskopu s prvkovou sondou.

\section{VÝSLEDKY}

Tab. 3 Výsledky prováděných zkoušek pro stanovení výsledných vlastností navržených směsí.

\begin{tabular}{ccccc}
\hline Směs & P-S10 & P-S15 & A-S10 & A-S15 \\
\hline Smrštění výpalem [\%] & 7,4 & 9,5 & 8,2 & 9,5 \\
Zdánlivá pórovitost [\%] & 33,2 & 27,8 & 21,7 & 19,6 \\
Nasákavost [\%] & 14,7 & 12,8 & 8,1 & 7,2 \\
Objemová hmotnost $\left[\mathbf{k g} \cdot \mathbf{m}^{-3}\right]$ & 2270 & 2210 & 2700 & 2740 \\
Žárovzdornost $\left[{ }^{\circ} \mathbf{C}\right]$ & 1683 & 1658 & 1723 & 1708 \\
Únosnost v žáru $\mathbf{T}_{\mathbf{0 , 5}}\left[{ }^{\circ} \mathbf{C}\right]$ & 1594 & 1562 & 1648 & 1653 \\
Pevnost v tahu za ohybu $[\mathbf{M P a}]$ & 15,4 & 18,7 & 16,3 & 20,1 \\
Reziduální pevnost $\mathbf{~}$ ohybu $[\mathbf{\%}]$ & 21,3 & 33,8 & 26,1 & 37,4 \\
\hline
\end{tabular}

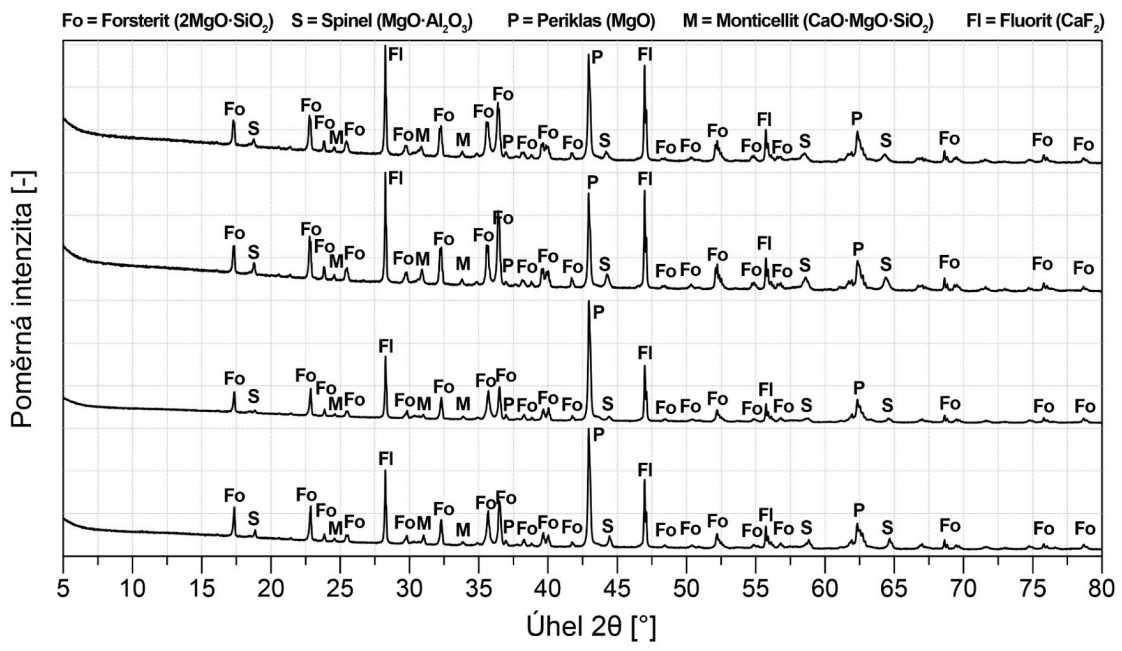

Obr. 1 Rentgenová difrakční analýza všech směsí. 
Tab. 4 Kvantitativní zastoupení minerálů a amorfní fáze ve všech směsích.

\begin{tabular}{ccccc}
\hline Minerál & P-S10 & P-S15 & A-S10 & A-S15 \\
\hline Forsterit $\left(\mathbf{2 M g O} \cdot \mathbf{S i O}_{2}\right.$ ) & 57,8 & 48,5 & 72,2 & 66,5 \\
Spinel $\left(\mathbf{M g O} \cdot \mathbf{A l}_{2} \mathbf{O}_{3}\right)$ & 11,1 & 14,2 & 9,8 & 14,7 \\
Periklas $(\mathbf{M g O})$ & 13,4 & 14,8 & 8,3 & 10,1 \\
Monticellit $\left(\mathbf{C a O} \cdot \mathbf{M g O} \cdot \mathbf{S i O}_{2}\right)$ & 2,7 & 2,2 & 1,6 & 2,0 \\
Amorfní fáze $\left(\mathrm{SiO}_{2}\right.$ ) & 14,9 & 20,4 & 8,1 & 6,7 \\
\hline
\end{tabular}

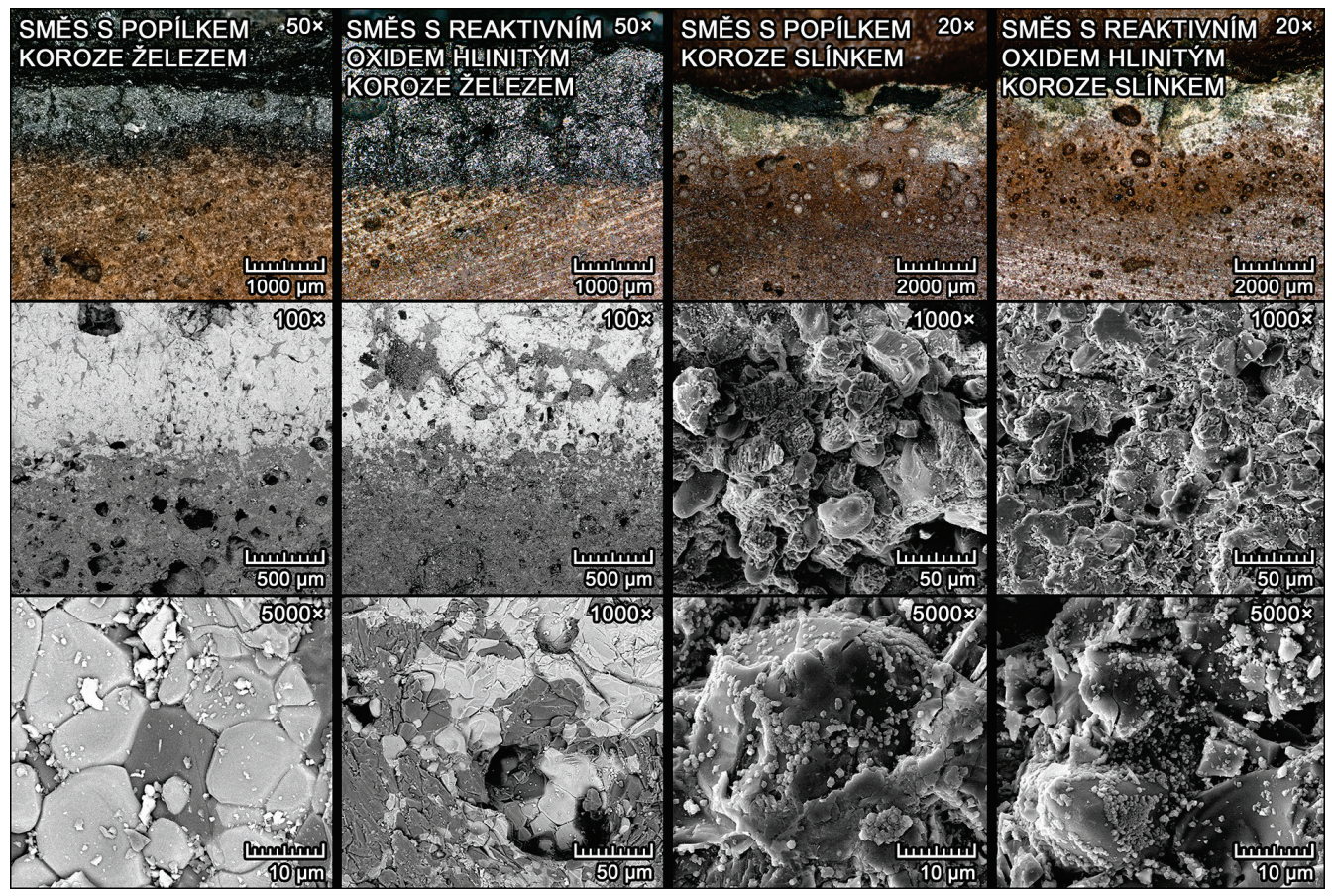

Obr. 2 Pozorování přechodné vrstvy pro vyhodnocení korozní odolnosti za pomoci optického a rastrovacího elektronového mikroskopu.

Tab. 5 Hloubka průsaku korozního média do všech směsí.

\begin{tabular}{ccccc}
\hline Hloubka průsaku & P-S10 & P-S15 & A-S10 & A-S15 \\
\hline Slínek [mm] & 3,1 & 3,0 & 2,5 & 1,8 \\
Železo [mm] & 2,7 & 2,2 & 2,1 & 1,5 \\
\hline
\end{tabular}

\section{DISKUZE}

Výsledky prováděných zkoušek pro stanovení vlastností všech směsí se nacházejí v Tab. 3. Smrštění výpalem bylo u všech směsí srovnatelné. Zdánlivá pórovitost a nasákavost byla nižší u směsí s reaktivním oxidem hlinitým, a to $\mathrm{v}$ důsledku menšího množství amorfní skelné fáze v těchto směsích. Díky nižší pórovitosti je objemová hmotnost směsí A-S10 a A-S15 vyšší než u směsí s popílkem. Směsi A-S10 a A-S15 mají taktéž vyšší žárovzdornost a únosnost $\mathrm{v}$ žáru než směsi s popílkem (P-S10, P-S15) kvůli nižšímu obsahu amorfní skelné fáze (Tab. 4) a menšímu množství tavících oxidů $\mathrm{Fe}_{2} \mathrm{O}_{3}$ a alkálií $\mathrm{Na}_{2} \mathrm{O}$ a $\mathrm{K}_{2} \mathrm{O}$ ve vstupní surovině (Tab. 1).

Pevnost v tahu za ohybu všech směsí je srovnatelná, vyšších hodnot bylo dosaženo u směsí s vyšším podílem spinelu (P-S15, A-S15). Vyhodnocením odolnosti proti změnám teplot lze dospět ke stejnému závěru, u směsí S vyšším podílem spinelu (P-S15, A-S15) bylo dosaženo lepší odolnosti proti změnám teplot. 
Vyhodnocením rentgenové difrakční analýzy (Obr. 1) lze dospět k závěru, že ve všech směsích se nacházejí minerály forsterit, spinel, periklas a monticellit. Fluorit byl do směsí přidán při prŕípravě prášků jako inertní standard pro přesné kvantitativní stanovení minerálů a amorfní fáze ve směsích (Tab. 4). Z výsledků kvantitativního zastoupení minerálů lze vidět, že obsah spinelu ve směsích koreluje s teoretickou hodnotou z návrhu směsí. Směsi P-S10 a P-S15 obsahují méně forsteritu na úkor vyššího obsahu amorfní skelné fáze, a to $\mathrm{v}$ důsledku přítomnosti vyššího množství tavících oxidů než ve směsích A-S10, A-S15 s reaktivním oxidem hlinitým. Ve všech směsích je také přítomen periklas, což je oxid hořečnatý, který nezreagoval s oxidem křemičitým za tvorby forsteritu. Př́tomnost monticellitu je dána obsahem oxidu vápenatého ve vstupních surovinách.

Obr. 2 znázorňuje výsledky korozní odolnosti, kdy na kelímky z navržených směsí působila korozní média po dobu 5 hodin při $1538{ }^{\circ} \mathrm{C}$ u železa a $1450{ }^{\circ} \mathrm{C}$ u slínku. Pozorováním přechodné vrstvy mezi keramikou a korozním médiem, jímž byly železo a slínek, lze určit hloubku koroze pomocí optického mikroskopu a vyhodnotit korozní odolnost navržených směsí. Přechodná vrstva při korozi železem je u obou směsí jasně viditelná a hloubka průniku železa do keramiky je minimální $(1,5-2,7 \mathrm{~mm})$. Pouze u směsí s popílkem je v přechodné mezivrstvě vyšší pórovitost. Při korozi slínkem je přechodná vrstva již méně zřetelná a lze již spatřit také tmavěji zbarvenou mezivrstvu, do které slínek pronikl. U obou směsích je v oblasti mezivrstvy také vyšší pórovitost. Celkovým vyhodnocením směsí vůči korozním účinkům železa a slínku lze konstatovat, že jejich korozní odolnost je dobrá, vzhledem $\mathrm{k}$ tomu, že hloubka průsaku korozního média je 1,8-3,1 mm.

\section{ZÁVĚR}

Ve všech navržených směsích byly přítomny minerály forsterit jako majoritní krystalická fáze a spinel, periklas a monticellit jako minoritní krystalické fáze. Podíl spinelu ve směsích se shodoval s teoretickým předpokladem při návrhu směsí. Žárovzdorné vlastnosti všech směsích byly téměr̆ totožné, u směsí s popílkem (P-S10, P-S15) byly mírně nižší v důsledku vyššího obsahu tavících oxidů ve vstupní surovině. Pevnosti v tahu za ohybu a odolnost proti změnám teplot se zlepšila ve směsích s vyšším podílem spinelu (P-S15, A-S15), což potvrdilo hypotézu, že přítomnost spinelu ve forsteritové keramice zlepšuje tyto vlastnosti.

Vyhodnocením korozní odolnosti směsí vůči korozi železem a slínkem lze konstatovat, že jejich korozní odolnost vůči železu je velmi dobrá, hloubka průsaku železa do keramiky byla minimální. Korozní odolnost vůči slínku u obou směsí byla srovnatelně dobrá, hloubka průsaku slínku do keramiky byla v jednotkách milimetrů.

\section{Poděkování}

Tento příspěvek byl podpořen v rámci řešení juniorského grantu specifického výzkumu pod interní grantovou agenturou Vysokého učení technického v Brně s číslem FAST-J-21-7279 a názvem: Vliv mikrostruktury žárovzdorné forsterit-spinelové keramiky na její vysokoteplotní chování a fyzikálně-mechanické vlastnosti.

\section{Použité zdroje}

[1] BUDNIKOV, P. P. a kolektiv. Technologie keramiky a žárovzdorného zboží. Praha: Státní nakladatelství technické literatury, 1960, ISBN 9780262523776

[2] KINGERY, W. Introduction to ceramics. New York: Wiley, 1960, xvi, 781 s. ISBN 04-714-7883-0.

[3] ZHAO, Fei, Lixin ZHANG, Zhen REN, Jinxing GAO, Xiaoyu CHEN, Xinhong LIU a Tiezhu GE. A novel and green preparation of porous forsterite ceramics with excellent thermal isolation properties, Ceramics International, 2019, 45(3), 2953-2961, ISSN 02728842, DOI: 10.1016/j.ceramint.2018.09.296

[4] BOUHIFD, M. A., D. ANDRAULT, G. FIQUET a P. RICHET. Thermal expansion of forsterite up to the melting point, Geophysical research letters, 1996, 23(10), 1143-1146

[5] HEILMANN, F.; Rixecker, G.; Börner, F.D.; Lippmann, W.; Hurtado, A. Fe2O3-doped forsterite ceramics as a joining partner for $\mathrm{ZrO} 2$ in a laser brazing process. Journal of European Ceramics Society, 2009, 29, 2783-2789, doi:10.1016/j.jeurceramsoc.2009.03.028

[6] MUSTAFA, E.; Khalil, N.; Gamal, A. Sintering and microstructure of spinel-forsterite bodies. Ceramics International 2002, 28, 663-667, doi:10.1016/S0272-8842(02)00025-1

[7] EWAIS, E.M.M.; El-Amir, A.A.M.; Besisa, D.H.A.; Esmat, M.; El-Anadouli, B.E.H. Synthesis of nanocrystalline $\mathrm{MgO} / \mathrm{MgAl} 2 \mathrm{O} 4$ spinel powders from industrial wastes. Journal of Alloys and Compounds. 2017, 691, 822-833, doi:10.1016/j.jallcom.2016.08.279

[8] AHMAD, H.B.; McKinnie, I.T. Chromium doped forsterite ring laser. Opt. Laser Technol. 1995, 27, 403-406, doi:10.1016/0030-3992(95)00031-3 
[9] KHARAZIHA, M.; Fathi, M.H. Synthesis and characterization of bioactive forsterite nanopowder. Ceram. Int. 2009, 35, 2449-2454, doi:10.1016/j.ceramint.2009.02.001.

[10] NI, S.; Chou, L.; Chang, J. Preparation and characterization of forsterite (Mg2SiO4) bioceramics. Ceram. Int. 2007, 33, 83-88, doi:10.1016/j.ceramint.2005.07.021.

[11] TAVANGARIAN, F.; Emadi, R. Synthesis of pure nanocrystalline magnesium silicate powder. Ceram. Silikat. 2010, 54, 122-127, ISSN 1804-5847.

[12] FATHI, M.H.; Kharaziha, M. Mechanically activated crystallization of phase pure nanocrystalline forsterite powders. Mater. Lett. 2008, 62, 4306-4309, doi:10.1016/j.matlet.2008.07.015.

[13] KUMAR, M.S.; Vanmathi, M.; Senguttuvan, G.; Mangalaraja, R.V.; Sakthivel, G. Fly Ash ConstituentSilica and Alumina Role in the Synthesis and Characterization of Cordierite Based Ceramics. Silicon 2018, 11, 2599-2611, doi:10.1007/s12633-018-0049-0.

[14] REN, Q.; Ren, Y.; Wu, X.; Bai, W.; Zheng, J.; Hai, O. Effect mechanism of spinel (MgAl2O4) reinforced corundum ceramics on microstructure and properties. J. All. Com. 2019, 793, 146-154, doi:10.1016/j.jallcom.2019.04.151

[15] DONG, Y.; Hampshire, S.; Zhou, J.; Ji, Z.; Wang, J.; Meng, G. Sintering and characterization of fly ashbased mullite with MgO addition. J. Eur. Ceram. Soc. 2011, 31, 687-695, doi:10.1016/j.jeurceramsoc.2010.12.012.

[16] CAO, J.; Dong, X.; Li, L.; Dong, Y.; Hampshire, S. Recycling of waste fly ash for production of porous mullite ceramic membrane supports with increased porosity. J. Eur. Ceram. Soc. 2014, 34, 3181-3194 doi:10.1016/j.jeurceramsoc.2014.04.011.

[17] PETRIC, A.; Ling, H. Electrical Conductivity and Thermal Expansion of Spinels at Elevated Temperatures. J. Am. Ceram. Soc. 2007, 90(5), 1515-1520, doi.org/10.1111/j.15512916.2007.01522.x. 